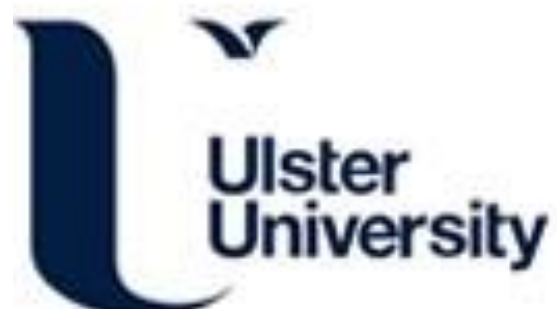

\section{Urban Challenges in India and the Mission for a Sustainable Habitat}

Ghosh, R., \& Kansal, A. (2014). Urban Challenges in India and the Mission for a Sustainable Habitat. INTERdiscip/pina, 2(2), 281. https://doi.org/10.22201/ceiich.24485705e.2014.2.46530

Link to publication record in Ulster University Research Portal

\author{
Published in: \\ INTERdisciplpina
}

Publication Status:

Published (in print/issue): 01/01/2014

DOI:

10.22201/ceiich.24485705e.2014.2.46530

\section{Document Version}

Author Accepted version

\section{General rights}

Copyright for the publications made accessible via Ulster University's Research Portal is retained by the author(s) and / or other copyright owners and it is a condition of accessing these publications that users recognise and abide by the legal requirements associated with these rights.

\section{Take down policy}

The Research Portal is Ulster University's institutional repository that provides access to Ulster's research outputs. Every effort has been made to ensure that content in the Research Portal does not infringe any person's rights, or applicable UK laws. If you discover content in the Research Portal that you believe breaches copyright or violates any law, please contact pure-support@ulster.ac.uk. 
http://www.journals.unam.mx/index.php/inter/article/view/46183

\title{
Urban challenges in India and mission for sustainable habitat
}

RuchiraGhosh, Research Scholar, TERI University, VasantKunj, New Delhi 110 070, ruchira_ewm@yahoo.co.in

ArunKansal*, Associate Professor, TERI University, VasantKunj, New Delhi 110 070, akansal@teri.res.in, Tele: 26122222, Fax 26122874

* Corresponding author

\begin{abstract}
This paper presents urbanization challenges in Indiaandinitiatives taken toaddress them. Urbanization in India is characterized by skewed urban growth between cities by large population influx creating distinct variation in core and peripheryof cities in terms of urban form and services. Key challenges include growth of slums, unscientific management of solid waste, decrease in per capita water availabilityand unreliable water quality, inadequate sewage coverage and deteriorating ambient air. Though, these issues are not new or particular for India, but what is new are the drivers and pressures behind these problems. The paper illustrates the challenges of Indian urbanization in the light of resource inefficiency, resistance to adopt upcoming technologies that do not have direct financial benefits, weak enforcement of laws, and inadequacy in regulatory framework. It also presents instances of active participation of nonformal and formal sectors in addressing sustainability challenges. There is also a recognition of the fact that city governments are faced with multiple sustainability agendas climate adaptation.This presents a decisional challenge for planners and the city administration.Benefits incidental to a particular policy goal can help drive the implementation of the policy and sustain it in long term, but only when the inherent risk trade-offs, if present, can be managed.
\end{abstract}

\section{Urbanization in India}

This is an urban century and India is also urbanizing at an enhanced pace in recent decades (Table 1). Hence, it presents a unique opportunity to plan, develop and build a new India which is ecologically and economically sustainable. The history of urbanization in India is quite old as towns and urban places flourished in the Indus Valley around 2000B.C.(Vesilund et al, 2002). During ancient and medieval periods, the urban centers were associated with the seeds of administration, trade and religion. After arrival of Europeans in India, urbanization rate was accelerated mainly because of the location and establishment of modern factories and industries. Urbanization in Indiaduring the past century was associated with a particular theme in each decade (Table 2). 
Table 1.Growth of urban population

\begin{tabular}{|l|l|l|l|}
\hline Year & $\begin{array}{l}\text { World urban population } \\
\text { (billions) }\end{array}$ & $\begin{array}{l}\text { Urban: Rural } \\
\text { (world) }\end{array}$ & $\begin{array}{l}\text { India Urban Population } \\
(\%)\end{array}$ \\
\hline 1950 & $0.74(29.44 \%)$ & $1: 2.34$ & $17.2^{2}$ \\
\hline 1960 & $1.02(33.55 \%)$ & $1: 1.98$ & $17.9^{2}$ \\
\hline 1970 & $1.35(36.58 \%)$ & $1: 1.73$ & $19.9^{2}$ \\
\hline 1980 & $1.75(39.37 \%)$ & $1: 1.54$ & $23.3^{2}$ \\
\hline 1990 & $2.28(42.99 \%)$ & $1: 1.32$ & $25.7^{2}$ \\
\hline 2000 & $2.85(46.68 \%)$ & $1: 1.14$ & $27.8^{2}$ \\
\hline 2010 & $3.56(51.6 \%)$ & $1: 0.94$ & $31.1^{3}$ \\
\hline
\end{tabular}

Source: ${ }^{1}$ UN department of Economic \& Social Affairs, Population Division, 2012;

${ }^{2}$ NIUA, 2011. Figure given are for the year 1951, 1961... respectively.

${ }^{3}$ Census of India, 2011

Table 2. Urbanization trends in India

\begin{tabular}{|l|l|l|l|}
\hline S.No. & Decade & Theme & Urban percentage \\
\hline 1. & $1901-1911$ & Famine and plague & 10.84 to $10.29^{1}$ \\
\hline 2. & $1911-1921$ & Influenza epidemic & 10.29 to $11.17^{1}$ \\
\hline 3. & $1921-1931$ & Agricultural depression & 11.17 to $11.99^{1}$ \\
\hline 4. & $1931-1941$ & War & 11.99 to $13.85^{1}$ \\
\hline 5. & $1941-1951$ & Partition of the Sub-continent & 13.85 to $17.29^{1}$ \\
\hline 6. & $1951-1961$ & Planned development & 17.29 to $17.97^{1}$ \\
\hline 7. & $1961-1971$ & $\begin{array}{l}\text { Emergence of new urbanization in backward areas and } \\
\text { concentrated urban development near big cities. }\end{array}$ & 17.97 to $19.90^{1}$ \\
\hline 8. & $1971-1981$ & Decentralized urban growth & 19.90 to $23.31^{1}$ \\
\hline 9. & $1981-1991$ & $\begin{array}{l}\text { Decelerated rural-urban migration and declining rate of } \\
\text { natural increase }\end{array}$ & 23.31 to $25.70^{1}$ \\
\hline 10. & $1991-2001$ & Decentralized urban planning and development & 25.70 to $27.82^{2}$ \\
\hline 11. & $2001-2011$ & Sustainable habitat & 27.82 to $31.1^{3}$ \\
\hline
\end{tabular}

Source: ${ }^{1}$ NIUA, 2011; ${ }^{2}$ Census of India $2001 ;{ }^{3}$ Census of India 2011

India is one of the least urbanized country of the world, yet its urban population is second largest amongst the countries of the world (City mayor, 2013).The India census recognizes six classes of cities and towns. Class I towns have a population of more than 100,000; Class II towns have a population ranging between 50,000 and 99,999. Class III towns have a range of population range from 20,000 to 49,000; Class IV towns from 10,000 to 19,999 and Class V towns from 5,000 to 9,999. Class VI towns have a population of less than 5,000. Another striking feature of the urban scene in India is currently there are 53metropolitan cities (Census of India, 2011). These metropolitan cities account for more than $42 \%$ of India's urban population (Table 3 ). 
In terms of regional disparity, Western and Southern India is more urbanized than Eastern and Northern India, mainly because of topography (Figure 1). Of the total urban population more than 50\% lives in just five states viz. Maharashtra, Uttar Pradesh, Tamil Nadu, West Bengal, and Andhra Pradesh (Table 4). States like Bihar, Orissa and Assam have urban population less than half the national average mainly because of lack of development of secondary and tertiary economic activities (NIUA, 2011).

Table 3.Distribution of urban population by city class

\begin{tabular}{|l|l|l|l|l|}
\hline Class Size & Population range & $\begin{array}{l}\text { Number of } \\
\text { cities }\end{array}$ & $\begin{array}{l}\text { Total Urban } \\
\text { population (\%) }\end{array}$ & $\begin{array}{l}\text { Urban population } \\
\text { (million) }\end{array}$ \\
\hline Mega cities & $>10$ million & 3 & 12.9 & 48.8 \\
\hline Million plus cities & $1-10$ million & 50 & 29.6 & 111.7 \\
\hline $\begin{array}{l}\text { Class I (excluding } \\
\text { million plus cities) }\end{array}$ & $0.1-1$ million & 415 & 27.6 & 104.2 \\
\hline Class II+III+IV+V+VI & $<0.1$ million & 7467 & 30 & 112.2 \\
\hline
\end{tabular}

Source: Census of India, 2011

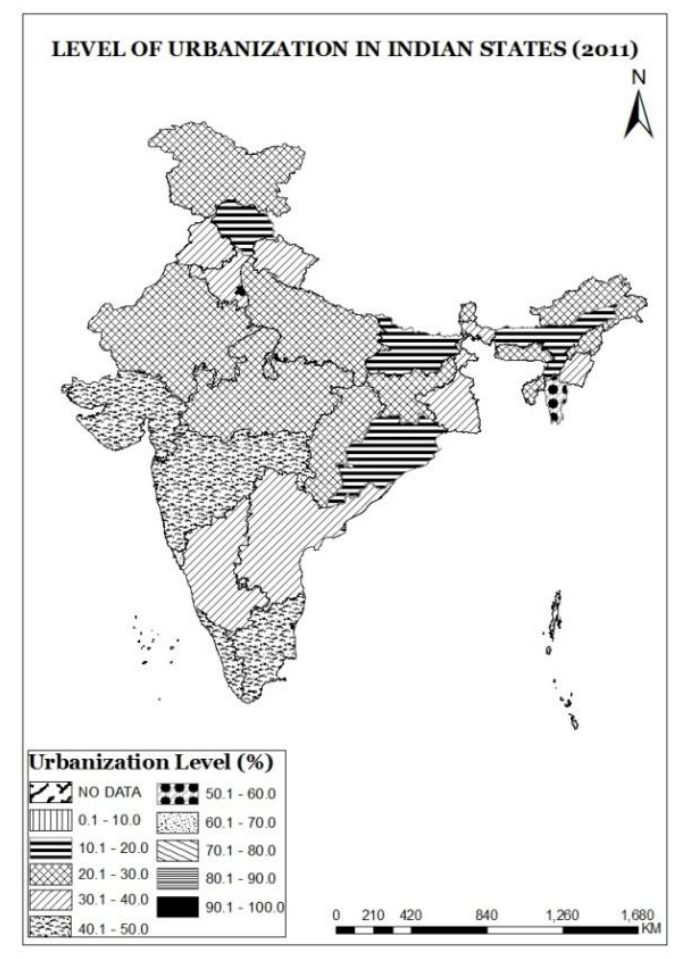

Figure 1. Urbanization in Indian states in 2011.(Source: Data sourced from Census of India, 2011) 
Table 4. Urban population in various States of India

\begin{tabular}{|l|l|l|l|l|l|}
\hline $\begin{array}{l}\text { States/Union } \\
\text { territory }\end{array}$ & $\begin{array}{l}\text { Total urban } \\
\text { population } \\
\text { (million) }\end{array}$ & $\begin{array}{l}\text { States/Union } \\
\text { territory }\end{array}$ & $\begin{array}{l}\text { Total urban } \\
\text { population } \\
\text { (million) }\end{array}$ & $\begin{array}{l}\text { States/Union } \\
\text { territory }\end{array}$ & $\begin{array}{l}\text { Total urban } \\
\text { population } \\
\text { (million) }\end{array}$ \\
\hline Maharashtra & $508.3(45.23 \%)$ & Punjab & $10.4(37.49 \%)$ & Manipur & $0.8(30.21 \%)$ \\
\hline Uttar Pradesh & $44.5(22.28 \%)$ & Haryana & $88.2(34.79 \%)$ & $\begin{array}{l}\text { Himachal } \\
\text { Pradesh }\end{array}$ & $0.7(10.04 \%)$ \\
\hline Tamil Nadu & $34.9(48.45 \%)$ & Jharkhand & $79.3(24.05 \%)$ & Meghalaya & $0.6(20.08 \%)$ \\
\hline West Bengal & $29.1(31.89 \%)$ & Orissa & $69.9(16.68 \%)$ & Nagaland & $0.6(28.97 \%)$ \\
\hline Andra Pradesh & $28.4(33.49 \%)$ & Chhattisgarh & $59.4(23.24 \%)$ & Mizoram & $0.6(51.51 \%)$ \\
\hline Gujarat & $25.7(42.58 \%)$ & Assam & $43.8(14.08 \%)$ & $\begin{array}{l}\text { Arunachal } \\
\text { Pradesh }\end{array}$ & $0.3(22.67 \%)$ \\
\hline Karnataka & $23.6(38.57 \%)$ & $\begin{array}{l}\text { Jammu \& } \\
\text { Kashmir }\end{array}$ & $34.1(27.71 \%)$ & Daman \& Diu & $0.2(75.16 \%)$ \\
\hline $\begin{array}{l}\text { Madhya } \\
\text { Pradesh }\end{array}$ & $20.1(27.63 \%)$ & Uttaranchal & $30.9(30.55 \%)$ & $\begin{array}{l}\text { Dadar\& Nagar } \\
\text { Haveli }\end{array}$ & $0.2(46.62 \%)$ \\
\hline Rajasthan & $17.1(24.89 \%)$ & Chandigarh & $10.3(97.25 \%)$ & Sikkim & $0.2(24.97 \%)$ \\
\hline Delhi & $16.3(97.49 \%)$ & Tripura & $96.1(26.18 \%)$ & $\begin{array}{l}\text { Andaman and } \\
\text { Nicobar }\end{array}$ & $0.2(35.67 \%)$ \\
\hline Kerala & $15.9(47.72 \%)$ & Goa & $90.6(62.17 \%)$ & Lakshadweep & $0.5(78.08 \%)$ \\
\hline Bihar & $11.7(11.3 \%)$ & Pondicherry & $85.0(68.31 \%)$ & & \\
\hline
\end{tabular}

Source: Census of India, 2011

Interesting differences are observed in the distribution of urban population among towns of different size categories. It is revealing that $70 \%$ of the India's urban population lives in Class I or more (Census of India, 2011). Large cities are growing at the expense of smaller cities (Figure 2). Many of the smaller towns belonging to Class-V and VI of the census are "grown-up" villages. They perform predominantly agricultural functions, collecting agricultural produce from the surrounding villages and marketing it. The Mandi (grain market) forms the hub of the town. A market springs up along the road which provides access to the Mandi. With the passage of time some local administrative functions were also sold to urban agglomeration and it acquired the characteristic features of a tehsil town.

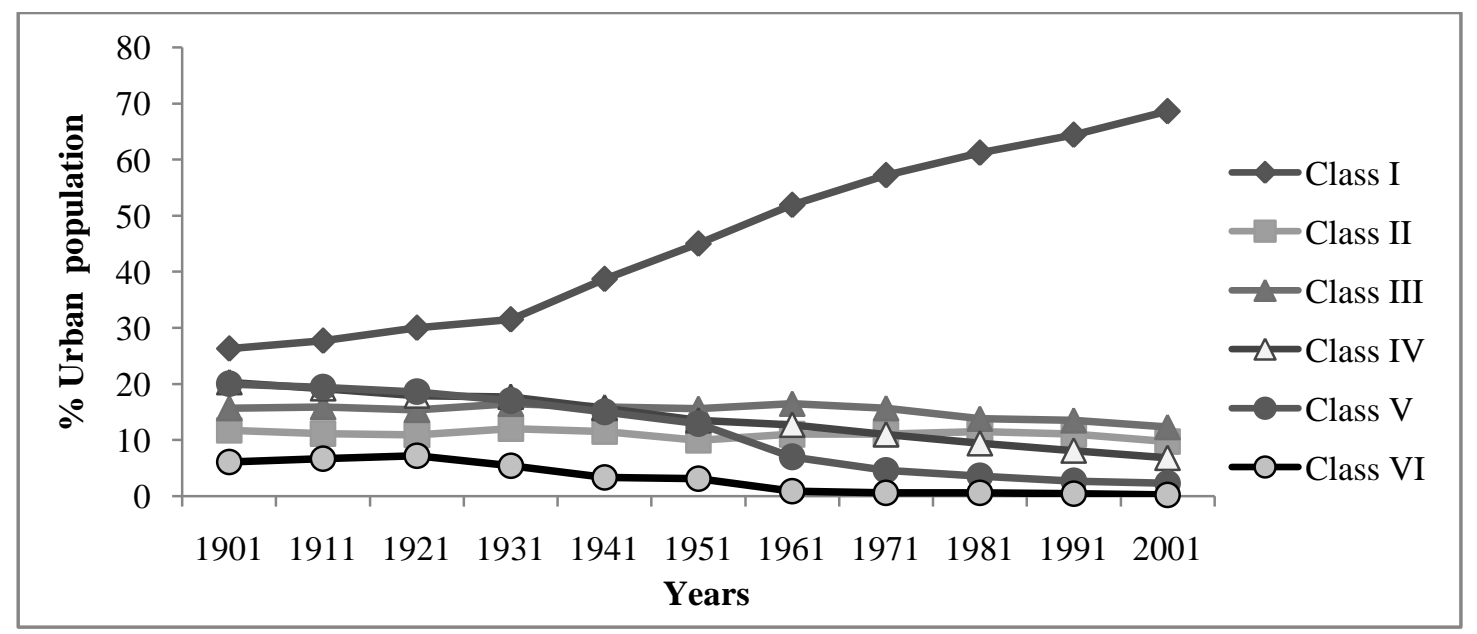

Figure 2. Trend of urbanization with city classification, (Source: Data sourced from NIUA, 2011) 


\section{Problems of Indian Urbanization}

First, is the manner in which urban areas are growing, most of the urban growth is taking place in slums (Table 5). This is because of the large scale out-migration of rural population into cities that are generally illiterate with minimum capital. Second, is the problem of one-sided growth of metropolitan cities at the expense of smaller towns (Table 6).Smaller towns failed to attract immigrants due to poor infrastructure and employment opportunities there. In big cities, population explosion and rural migration is hampering the provision for adequate water supply, education facilities, traffic and housing. Fore.gin Pune, only 29\% coverage of metered water supply connection exists and sewerage network has collection efficiency of $73.35 \%$ (PMC, 2013).Similarly, to satisfy urban education demand,schools are constructed but out of 62874 schools in urban area, only $52.16 \%$ had playground, suffers from lack of black boards (14.95\%), furniture (18.23\%), and 1693 primary schools do noteven have school building (NCERT, 2002). Also, social health in India has deteriorated by increase in urban malaria from $7.79 \%$ (1996) to $13.8 \%$ (2010) (Planning Commission, 2011a).Third, is the problem of core Vs periphery regions. The core region has traffic congestion, mixing up of small-scale industries and residential settlements. Periphery regions are generally the dump yard of the core and also have some residential housing of low income group with lack of civic amenities.

This has resulted in widening gap between rich and the poor causing urban crime, street children, prostitution, drugs and associated juvenile crime. Tertiary effect of this is environmental pollution, breakdown of culture and problem of mental stresses.

Table 5.Slum population in few major cities of India

\begin{tabular}{|l|l|l|}
\hline Cities in India & $\begin{array}{l}\text { Urban population } \\
(‘ 00000)\end{array}$ & Slum population (\%) \\
\hline Mumbai & 119.2 & 48.8 \\
\hline Faridabad & 10.5 & 46.5 \\
\hline Meerut & 10.7 & 43.8 \\
\hline Nagpur & 20.5 & 35.4 \\
\hline Kanpur & 25.3 & 35.4 \\
\hline Kolkata & 45.8 & 32.5 \\
\hline Bhopal & 14.3 & 22.5 \\
\hline Pune & 25.4 & 20.9 \\
\hline Delhi & 98.2 & 18.8 \\
\hline Chennai & 42.2 & 17.7 \\
\hline Hyderabad & 34.5 & 17.4 \\
\hline
\end{tabular}

Source: Slum census of India, 2001 
Table 6.Disproportionate growth of urban population in India

\begin{tabular}{|c|c|c|c|c|c|}
\hline Class Size & $\begin{array}{l}\text { Population } \\
\text { range }\end{array}$ & $\begin{array}{l}\text { Number of } \\
\text { cities }\end{array}$ & $\begin{array}{l}\text { Urban } \\
\text { population }(\%)\end{array}$ & $\begin{array}{l}\text { Average per } \\
\text { city }(\%)\end{array}$ & $\begin{array}{l}\text { Factor (no. of } \\
\text { times) }\end{array}$ \\
\hline Mega cities & $>10$ million & 3 & 12.9 & 4.3 & 7.1 \\
\hline Million plus cities & $1-10$ million & 50 & 29.6 & 0.6 & 10 \\
\hline $\begin{array}{l}\text { Class I (except } \\
\text { million plus cities) }\end{array}$ & 0.1-1 million & 415 & 27.6 & 0.06 & 15 \\
\hline $\begin{array}{l}\text { Class } \\
\mathrm{II}+\mathrm{III}+\mathrm{IV}+\mathrm{V}+\mathrm{VI}\end{array}$ & $<0.1$ million & 7467 & 30 & 0.004 & \\
\hline
\end{tabular}

Source: Census of India, 2011

The morphology of towns in India has its own peculiarities. There is hardly any difference between residential and the commercial areas. There exists social segregation due to existence of artesian and caste based colonies. The municipal administration very often makes a distinction between high-income and low-income colonies in providing civic amenities. The residential locations of low income groups often degenerate into slums. Moreover, Indian urbanization is of subsistence in nature as migrants from rural areas are attracted to the urban centers not for urban environment but for employment, i.e. push of poverty in the rural areas has been very acute. No functional or spatial integration exists in Indian urbanization. Due to this, there are breaks and imbalances in urban hierarchy. The urban base in rural areas is sub-standard and the intermediary link through the market towns is week.

\section{Sustainability challenges of urban growth in India}

\subsection{Housing and slums}

Indian urbanization is characterized by growth in slum population (Figure 3). A rural migrant with low affordability to rent houses in core areas of cities end up in slum formation in the periphery, resulting in haphazard and unplanned urbanization. Around 30\% of the urban population in India live in poor quality, overcrowded accommodation with inadequate or no provision for basic infrastructure and services (NIUA, 2011). They are also the ones who can least afford high transportation costs, live on the periphery and hence system contributes to a self-perpetuating cycle of poverty. They also face legal barriers to get access to electricity, land tenancy, power connections with an impact on safety of the end users. It deepens the cultural, economic and social gap between rich and poor and hence poses real hindrance to attaining sustainability. These settlements facemuch risk and vulnerability to climate change also. 


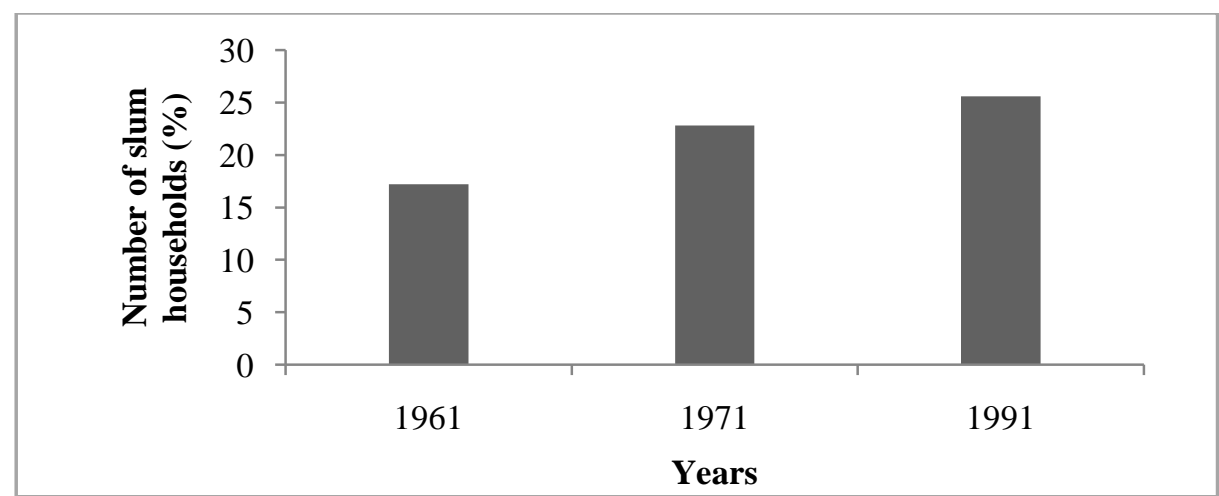

Figure 3. Number of slums (\%) in total households of Ahmadabad, India,(Source:Data sourced from UNSHP, 2010)

The Government of India (GoI) has initiated schemes as Rajiv AwasYojana (Rajiv housing scheme). An amount of INR 1803 billion has been spent for construction of 32,817 housing units in 34 cities.Some other institutional initiatives taken are construction of houses for Government employees and weaker sections, provision for rural housing, slum clearance and sweepers housing (Dwivedi, 2007) and enactment of Urban Land (Ceiling and Regulation) Act 1974. To prevent one-sided (or skewed) urban growth, the GoI attempted to improve rural-urban networksand launched Integrated Development of Small and Medium Towns (IDSMT) scheme for towns below 0.1 million population which includes extending finances to civic agencies for provision of roads, pavements, bus stands, markets, shopping complex etc (Dwivedi, 2007). However, all these schemes were not uniformly implemented.

\subsection{Municipal waste}

India generates more than 40 milliontonneof municipal waste annuallyfrom urban centers (World Bank, 2006) whichis collected poorly (average collection efficiency is $72 \%$, Figure 4), transported inadequately $(70 \%$ cities lack required transportation capacities) and disposed unscientifically (no sanitary landfill for municipal wastes exists, Figure 5) (Kansal, 2002). Considered as a low priority area, solid waste management (SWM) was never taken seriously, either by public or by concerned agencies. Prevailing SWM systems in Indian cities are publically operated through municipalities, which are already overburdened and have not been very effective as far as services are concerned. People involvement is normally limited to payment of some obscure and indirect taxes. Moreover, there is an absence of well-formulated guidelines and policies regarding waste management services (Kansal, 2001). 


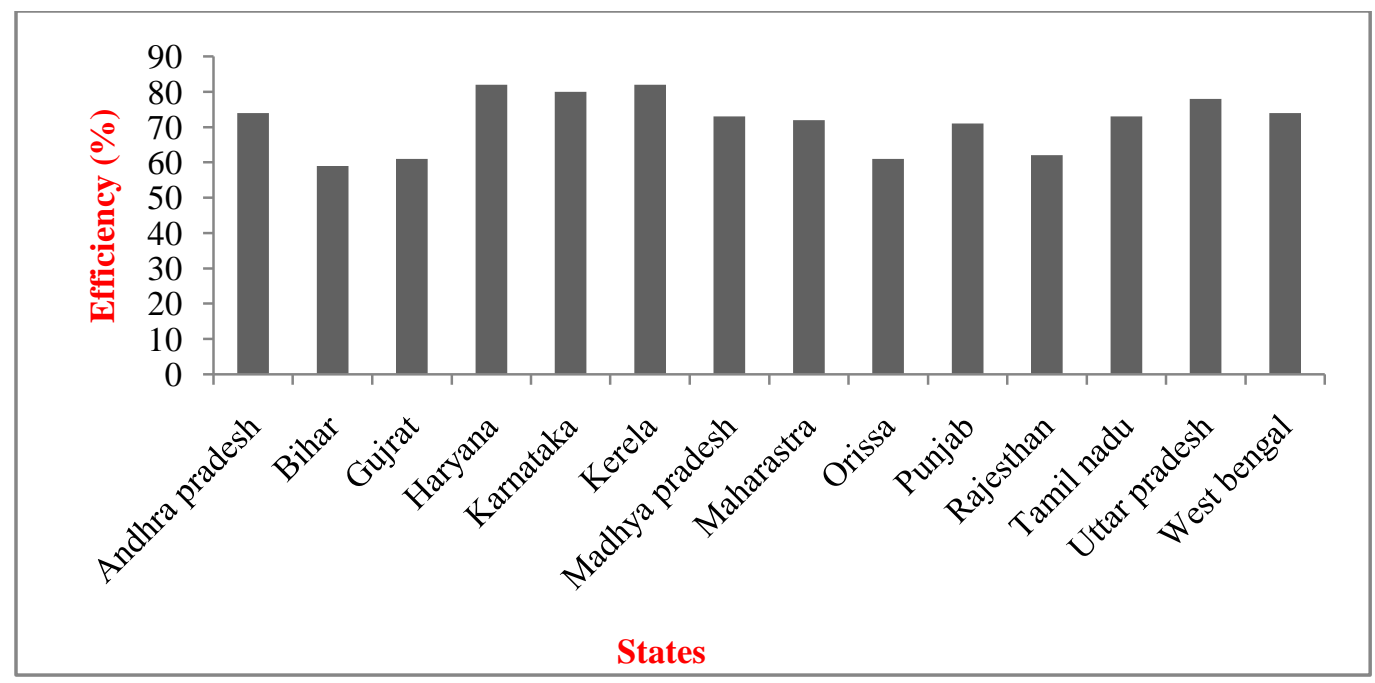

Figure 4.Solid waste collection efficiency in different states of India, (Source: Data fromNema, 2004; Sharholy et al., 2008)

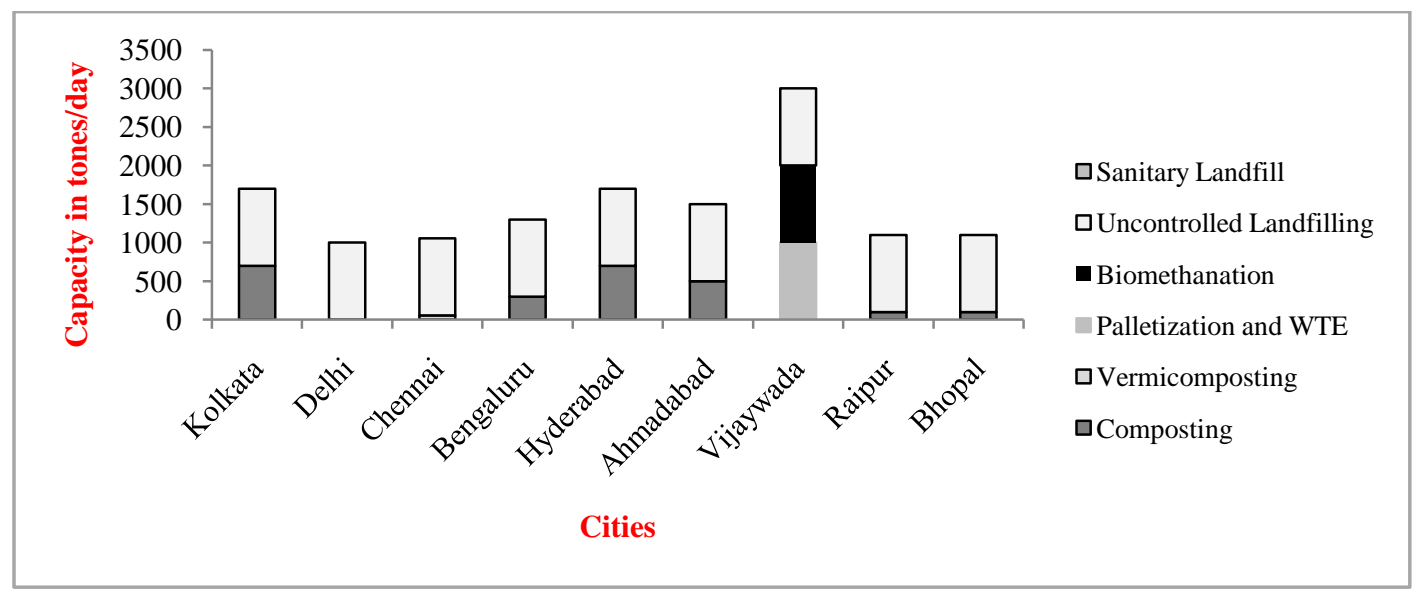

Figure 5.Municipal waste disposal practices in Indian cities (Source: Data sourced from Kumar et al, 2009).

Door to door primary collection system is absent except for some experiments run by nongovernmental organizations (NGOs) and self-help community groups. Multiple handling of garbage during the course of collection/removal is quite common (TERI, 2010). Uncontrolled dumping of waste on the outskirts of towns and cities has created overflowing landfills, which are not only impossible to reclaim because of haphazard manner of dumping, but also have serious environmental implications in terms of ground water pollution and contribution to global warming. Burning of waste leads to air pollution in terms of increased total suspended particulate emissions in air (Kansal, 2001). In the absence of waste segregation practices, recycling has remained an informal sector using outdated technology, but nevertheless thriving owing to waste material availability and market demand of cheaper recycled products(Uterikamp, 2011; 
Narayana, 2009). Paper and plastic recycling have been especially growing due to continuously increasing consumption levels of both the commodities (TERI, 2006).

However, there are certain good points. The per capita waste generation in India is low (0.3-0.6 $\mathrm{kg} /$ day) compared to many other developing countries (Pakistan- $0.8 \mathrm{~kg} / \mathrm{day}$, Sri-Lanka- 0.2-0.9 $\mathrm{kg} /$ day, Indonesia-0.8-1 kg/day) and developed countries (US- $2.1 \mathrm{~kg} / \mathrm{day}$, Germany- $1.56 \mathrm{~kg} / \mathrm{day}$, Italy- 1.55 kg/day) (Shekdar, 2009; Batool et al, 2009; Troschinetz\&Mihelcic, 2009; OECD factbook, 2009). A large number of formal and non-formal sectorshave emerged in waste management (Box 1) and there are good numbers of cases of positive intervention from NGOs, resident associations, and other action groups. However, the impact of such efforts on the overall deteriorating situation is much insignificant and there is an urgent need to have strategies that would look into the overall aspect of solid waste management (Shekdar, 2009).

\section{Box 1: Examples of institutionalised waste management}

- Initiative by Urban local body (IPE,2004)

Chennai Municipal Corporation-community waste management: 4000 million tonsof waste generated by Chennai annually, where Chennai Municipal Corporation shares the responsibility for procurement of vehicle, collection bins, and transfer to disposal sites with private contractor, NGO-EXNORA. The NGO trains rag pickers for door-door collection, transport to collection bins, vermi-composting, aerobic composting, and enhancing capacity of urban managing body.

- Private sector participation, source (IPE,2004)

Navi Mumbai Municipal Corporation: It manages street cleaning and transportation of waste to dumpsite in 82 zones in a joint venture with private managing body. This helped in $40 \%$ cost reduction, $450-500$ less sanitation worker requirements.

- Role of Informal sector, (Sharholy et al, 2008)

Rag pickers: Rag pickers collects waste in India (10-15 kg/day/head), saving USD 13,700 daily in Delhi, USD 200000 in Pune (as an example) and also reduces waste load on dumpsites (15\% reduction in waste dumping in Bangalore).

\subsection{Water supply and Sanitation}

The major issue is decrease in per capita water availability, unreliablewater quality and inadequate coverage (Planning Commission, 2008). Inadequate recharge of groundwater aquifers due to formation of impervious surface, increase distance of surface water sources and

exponential increase in water demand has contributed to decrease in per capita availability. For e.g. there has been exponential growth of water demand in Delhi from 650 MGD in 2002 (13.8 million population in 2001) to 859 MGD in 2012 (16.7 million population in 2011) (Census of India, 2011; Economic Survey of Delhi, 2012-13) laying pressure on water intake system. 
Agriculture runoffs and uncontrolled pollution from diffused sources have introduced new forms of pollutants and the conventional water treatment plants are not equipped to deal with these pollutants (Box 2). This resulted in disruption of water supply aggravating the problem of water availability. Apart from pollution, old constructed pipelines and inadequate operation and maintenance results in poor quality of service delivery (CPCB, 2000). In India growth of domestic water purifiers and the bottled industry has shown a phenomenal growth (Planning Commission, 2011b), resulting in more energy consumption and wastage of fresh water due predominant use of membrane based filtration for the production (CPCB, 2011).Slums and illegal settlements are supplied water through tankers often with unreliable quality and at a high cost.This has further widened the disparity between service delivery to urban rich and to poor. Poor end up paying 3 to 5 times more the cost of water whereas; rich are enjoying the benefits of subsidy to water pricing. However, some initiatives have been taken by private bodies to improve water supply to low income groups(Box 3).All three issues add another dimension of water-energy-climate nexusin urban water supplies (Plappally et al, 2012).Despite of legislation, laws and acts (Box 4), urban water supply system still offer challenges to sustainable urbanization.

\section{Box 2: Disruption of water supply in Delhi due to rise in ammonia in raw water}

During the month of February in 2011, the rates of supply water of Delhi has been shut down from two of its water treatment plants (combined capacity of 210 MGD), resulted in $35 \%$ less supply of water during the month. The reason attributable for shutting down water supply is the presence of ammonia in raw water for which the treatment plant has not been designed. The ammonia present in water is due to the discharge of industrial waste water and agricultural runoff carrying canal into the River Yamuna by the upstream regions of Delhi. This incidence happened in consecutive years.

Source: The Hindu, 2011

\section{BOX 3: Water supply through private bodies and residents participation in Delhi}

Unauthorized colonies in Delhi are not provided with water supply pipelines by unban utilities. They are provided water through motorized tankers. The chaotic condition due to limited numbers of tankers and huge population, results in wastage and contamination of water. Private body 'Force' and 'Water aid' has set up over-head water tankers and pipelines with the cooperation of residents in some regions of Delhi to address the problem. The tankers are either made up of RCC or Syntax where operation and maintenance is the responsibility of residents.

Source: Hindustan Times, 2012 


\section{BOX 4: Government initiatives}

- The agenda of water supply and sanitation was added during the first fiveyear plan (1951-1956).

- In 1954, the first national water supply program was launched to improvise health plan

- $\quad$ The Ministry of Water Resources (MoWR) drafted National Water Policy in 1987 for planning and development of water resources throughout the country, which includes design standards for groundwater structures, water quality monitoring, and data management and valuation

- National Water Policy was revised as National Water Policy 2002, with priority to safe drinking water to all.

- In order to improve urban water supply and sanitation services, guidance to states and cities are being provided.

Source: JNNURM, 2011; MoUD, 2012

4861 out of the 5161 cities/towns in India do not have sewerage network (Figure 6).Out of total wastewater generated, less than $29 \%$ in class I city and less than $3.67 \%$ in class II city is treated (NIUA, 2011; CPCB, 2005). Slum population in these cities depends on public toilets (Census of India, 2011) which are generally devoid of water supply (NIUA, 2011) and hence open defecation is still being practiced by significant population.Out of 423 cities surveyed, 190 cities are found to be vulnerable towater related epidemics (MHFW, 2008). GoI has formulated National Urban Sanitation Policy, 2008 (Box 5) that emphasizes on integration of institutions, enhancing sanitation infrastructure, sewage treatment facilities and mechanism of fixing responsibility and accountability.

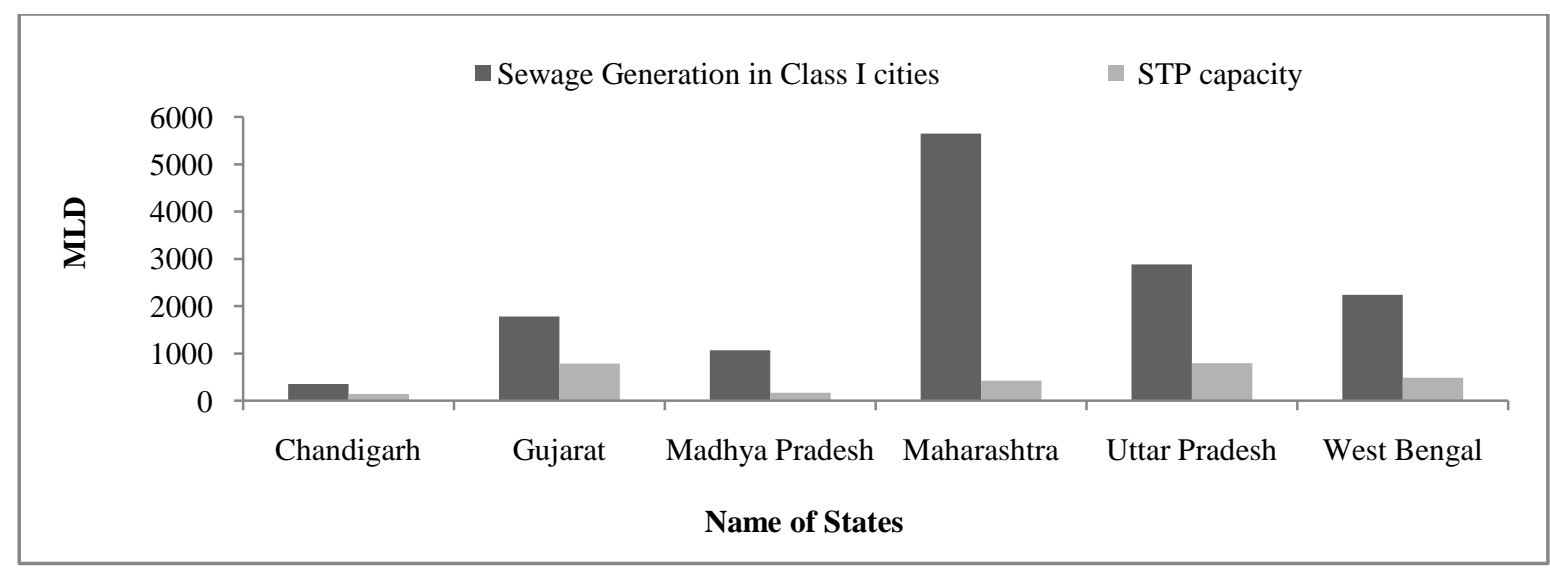

Figure 6. Sewage generation and sewage treatment plant capacity in few Indian States, (Source: Data sourced from CPCB, 2005) 
BOX 5: Key features of national urban sanitation policy, 2008

- Development of city sanitation plan and national level investment in urban infrastructure for urban households including slums.

- The urban local body needs to strengthen schemes for city sanitation by fixing tariffs, reforming operation and maintenance of sewage treatment plant, implementation of new sewerage system for new housing colonies.

- Integration of central, state, and local bodies to resolve issue of tenure and space in providing sanitation facilities for poor

- Capacity building of urban local bodies, awareness to public about sanitation and disease proliferation

- States are mandated to set up regulatory mechanisms through an independent agency for setting standards, monitoring performance, adjusting tariffs, etc.

Source: MoUD, 2008

\subsection{Air Pollution}

One of the major concerns of urbanization in India is deteriorating ambient air quality.Urban transport, manufacturing industries, thermal power plants, and domestic fuel combustion are major sources of human induced air pollutant emission likesulphur dioxide $\left(\mathrm{SO}_{2}\right)$, nitrogen oxides(NOx), particulate matter (PM) and hydrocarbons(HC) (CPCB, 1995; CPCB, 2000). Out of 142 cities surveyed through National Air Quality Monitoring Program (NAMP), 9 cities exceeds National Ambient Air Quality Standards (NAAQS) for NOx (exceeds 6\%), 96 cities for $\mathrm{PM}_{10}$ (exceeds 68\%), but level of $\mathrm{SO}_{2}$ are reported to be within permissible limits for residential /industrial areas(CPCB, 2011). The reason for such trend is reduction in sulphur content in vehicular fuel, use of cleaner fuel like compressed natural gas (CNG) in metropolitan cities maintaining $\mathrm{SO}_{2}$ and nitrogen dioxide $\left(\mathrm{NO}_{2}\right)$ level in ambient air. But increase in number of vehicles, extensive use of gensets, small-scale industries and incineration units without adequate air pollution control devices, suspension of traffic dusts results in high level of PM in Indian cities. Moreover, vehicular sources contribute about $58.5 \%$ of the total pollutants emitted, followed by thermal power and industries (30\%) and domestic sector and background concentration is (Kansal, 2011).

\subsubsection{Vehicular emission}

The vehicular stock trend in India is similar to that of the urban population (Eurostat Statistics, 2010; MoRTH, 2009), including skewed concentration in few megacities. Comparing transport situation of India with developed nations, the per capita vehicular ownership in India isvery low. For e.g. Germany has a high per-capita number of vehicles - 0.558 (Eurostat Statistics, 2010) compared to India 0.006 (World Resource Institute, 2011), but is low in the absolute number of 
vehicles in comparison to India, the respective numbers being 50,184,000 (Eurostat Statistics, 2010) and 89,618,000 (MoRTH, 2009), respectively. Similarly, the driving force of the motorization rate in Germany is comfort and lifestyle whereas, in India, it is a necessity due to the poor public transport system. The high purchasing power of Germans has resulted in significantly higher share of four-wheelers in the total vehicle stock (83\%, Eurostat Statistics, 2010); whereas, in India, due to low purchasing power two-wheelers have the major share (72\%, MoRTH, 2009). Public transportation, both railways and road, in Germany functions well, but $73 \%$ people use their personal motor vehicles (UBA, 2009). In India, about $85 \%$ of the passenger transport is carried out by road (Transport India, 2010; World Bank, 2002). City bus services operate in 17 cities, while rail transport exists only in 4 out of the 35 metropolitan cities of India (Singh, 2005). Traffic congestion is one of the problems caused partly by poor public transportation system. For example, due to traffic congestion in Delhi, the average speed has dropped to $15 \mathrm{~km} / \mathrm{h}$ and is expected to decline further (Mail Today, 2010). Moreover, urban areas in India have expanded horizontally, thereby increasing passenger travel demand. The Average Trip Length (ATL) in Indian mega-cities is about two times higher than in Germany, e.g. in Bangalore 12-13 km (Pangotra and Sharma, 2010), Mumbai 12.4 km (MMRDA, 1999), and in Delhi $10 \mathrm{~km}$ (Bose, 2001). The Vehicular Travel Demand (VTD) in India is approximately 4200 million passenger kilometers (Pangotra and Sharma, 2010) which is about 4.6 times higher than found in developed countries. The per-capita trip rate (PCTR) in India ranges between 1.0 - 1.7 [Mumbai PCTR is 1.7 (MMRDA, 1999), Delhi PCTR 1 (DUEIIP, 2000), and Bangalore PCTR is 1.2 (Pangotra and Sharma, 2010)]. The reason behind the significantly lower PCTR in India lies in the employment structure, where SMEs employ a significant number of people and are often located in or near residential areas. Therefore, many people do not have to travel to work.

Factors attributable to high emissions from vehicles in India are: a high proportion of old vehicles on the road using out-dated technology, two-stroke engine two-wheelers, a high number of personalized vehicles, high passenger kilometer demand and poor public transport infrastructure. Studies have shown that two-stroke engines are inefficient in fuel burning (Pundir, 2001), thereby resulting in higher levels of emissions (Figure 7). 


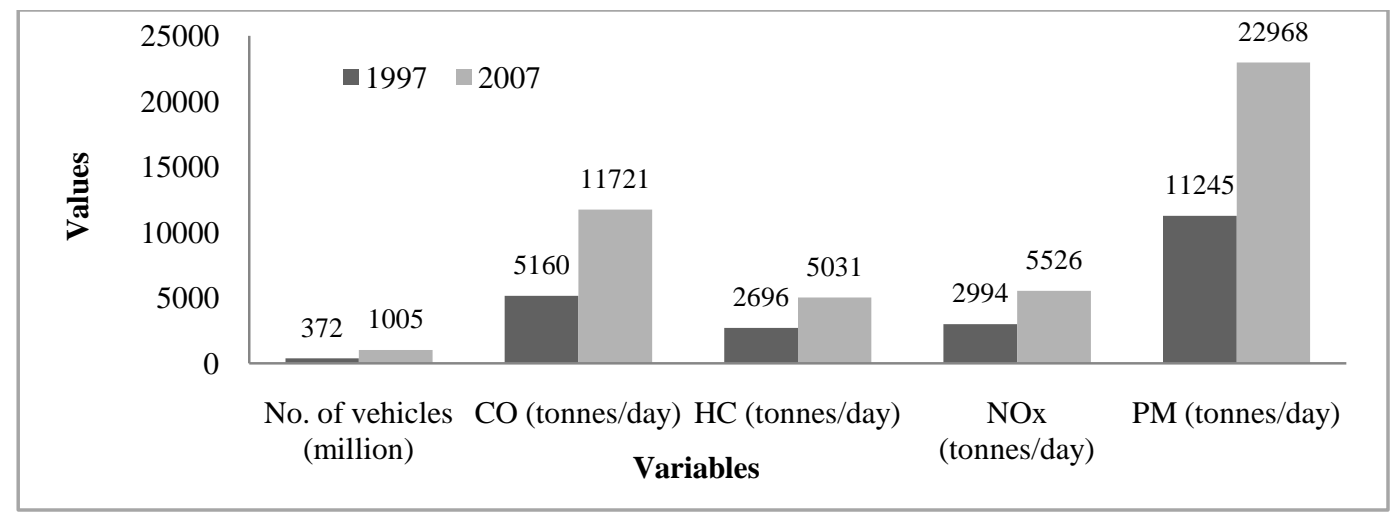

Figure 7. Increase in number of vehicles and associated emission in India from 1997 to 2007, (Source: Data sourced from MoRTH, 2004, SIAM, 2008)

The impact of vehicular pollutants is greater as these are ground-level emissions. The steps taken by the government to curb vehicular pollution in recent years are given in Table 7 . In addition to these, in December 2002, following the Supreme Court (apex court in India) order, Delhi has achieved the distinction of having the largest fleet of CNG (compressed natural gas) buses in the world, numbering over 7400 buses and over 4000 mini-buses. Entire fleet of Taxis (15000) and 3-wheelers (about 45,000) have already been converted into CNG powered engines. Following Delhi, are the cities of Beijing and Seoul in world where the number of CNG buses are around 1600 and 1000, respectively. Further, the Supreme Court directives read: 'The Union of India will give priority to the transport sector, including private vehicles all over India with regard to the allocation of CNG'. This means that in Delhi and other cities of India, CNG will be allocated on priority basis and made available for transport sector.

However, the missing ingredient in current air pollution strategies is the travel demand management. It is desirable to complement the 'supply-side interventions' with 'demand management measures', if the ultimate objective is to secure improved levels of air quality. They range from simple traffic engineering interventions (coordinated signals, reversible lanes, oneway street pairs, and other traffic control devices) to traffic restraints (area licensing schemes, parking controls, exclusive pedestrian zones, vehicle bans, special bus and high occupancy vehicle lanes and so on), advance traffic control techniques, and provision of facilities and services to encourage modal shifts (such as sidewalks, bicycle lanes, light and rapid rail transit, and commuter rail). All these measures would require a policy framework encompassing regulatory, pricing, and taxation mechanisms, and are to be reinforced with effective enforcement so as to encourage the use of clean vehicles and fuels and to modify travel behavior and transport demand. 
Table 7. Policy measures for vehicular and industrial pollution control in India.

\begin{tabular}{|c|c|c|}
\hline $\begin{array}{l}\text { Air quality control } \\
\text { measure }\end{array}$ & India & Remarks \\
\hline $\begin{array}{l}\text { Emission norms for } \\
\text { vehicles }\end{array}$ & $\begin{array}{l}\text { Started with Central Motor Vehicles Rules } \\
\text { in 1989, introduced Euro equivalent norms } \\
\text { in 2001, currently having Euro IV norms. }\end{array}$ & $\begin{array}{l}\text { India broadly followed European path for } \\
\text { emission norms with a time lag of } 4-5 \\
\text { years. }\end{array}$ \\
\hline $\begin{array}{l}\text { Emission norms for } \\
\text { industry }\end{array}$ & $\begin{array}{l}\text { Started with the Environment (Protection) } \\
\text { Act in 1986, Minimum National Standards } \\
\text { are in place for several categories. }\end{array}$ & $\begin{array}{l}\text { In India, both the number and diversity of } \\
\text { industry is large causing weak enforcement } \\
\text { of regulatory measures as compared to } \\
\text { Germany, where, due to smaller number of } \\
\text { large scale industries, regulatory measures } \\
\text { are easier to implement. }\end{array}$ \\
\hline 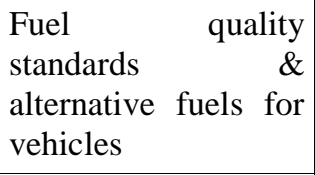 & $\begin{array}{l}\text { Fuel quality standards introduced in 1996, } \\
\text { lead phased-out in 1998. CNG-powered } \\
\text { public transportation (Delhi), ethanol } \\
\text { blended (5\%) petrol. }\end{array}$ & $\begin{array}{l}\text { Regulatory and economic instruments are } \\
\text { introduced to meet Euro (equivalent) } \\
\text { norms for reducing emissions. }\end{array}$ \\
\hline 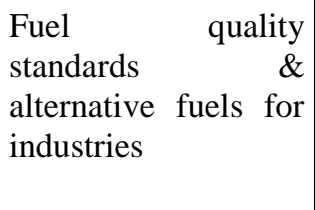 & $\begin{array}{l}\text { Started with the Environment (Protection) } \\
\text { Act in 1986, differentiated norms indicated } \\
\text { in legislation, low ash content required. } \\
\text { Partial substitution of fossil fuels with bio- } \\
\text { fuels, 'cleaner' fossil fuels. }\end{array}$ & $\begin{array}{l}\text { India needs strong public support and } \\
\text { involvement for successful implementation } \\
\text { of renewable in industrial sectors. }\end{array}$ \\
\hline $\begin{array}{l}\text { Technology } \\
\text { improvements for } \\
\text { vehicles }\end{array}$ & $\begin{array}{l}\text { Catalytic converters introduced in 1995, } \\
\text { Built-in-on-board diagnostic system and } \\
\text { electric cars pilot level. }\end{array}$ & $\begin{array}{l}\text { India has followed the path of } \\
\text { technological innovations of Germany with } \\
\text { a significant time lag due to the } \\
\text { expensiveness of technology upgrades. }\end{array}$ \\
\hline $\begin{array}{l}\text { Technology } \\
\text { improvements for } \\
\text { industries }\end{array}$ & $\begin{array}{l}\text { Promotion of best available technologies, } \\
\text { not mandatory: e.g. Filters, smoke gas } \\
\text { cleaning systems, Low } \mathrm{NO}_{\mathrm{x}} \text { burners. }\end{array}$ & $\begin{array}{l}\text { In India high number of (often illegal) } \\
\text { small and medium size enterprises (SME) } \\
\text { are not able to implement less polluting } \\
\text { processes and pollution control equipment } \\
\text { due to high cost involved. }\end{array}$ \\
\hline $\begin{array}{l}\text { Planning activities } \\
\text { for transportation } \\
\text { sector }\end{array}$ & $\begin{array}{l}\text { Restriction on goods vehicles, time clocks } \\
\text { on traffic lights, road construction incl. bus } \\
\text { lanes etc. }\end{array}$ & $\begin{array}{l}\text { India focuses on infrastructure } \\
\text { development before it can move on to } \\
\text { setting stricter traffic restriction. }\end{array}$ \\
\hline $\begin{array}{l}\text { Planning activities } \\
\text { for industrial sector }\end{array}$ & $\begin{array}{l}\text { The Policy Statement on Abatement of } \\
\text { Pollution } 1992 \text { integrates environmental } \\
\text { concerns into decision making, incl. } \\
\text { licensing; creation of Zoning Atlas; heavily } \\
\text { polluting industries are shifted to } \\
\text { undeveloped areas inside the country. }\end{array}$ & $\begin{array}{l}\text { In India, there are continuous problems } \\
\text { with the land-use pattern and with } \\
\text { following the licensing procedure. Many } \\
\text { industries are located in residential areas } \\
\text { and the other way round. }\end{array}$ \\
\hline $\begin{array}{l}\text { Emissions' } \\
\text { Information } \\
\text { provision }\end{array}$ & $\begin{array}{l}\text { Emissions' info is published, and displayed } \\
\text { in bigger cities. }\end{array}$ & $\begin{array}{l}\text { In India, industrialists are not required to } \\
\text { report their emissions, resulting in caps in } \\
\text { the emissions' data and weak control over } \\
\text { the emissions. }\end{array}$ \\
\hline $\begin{array}{l}\text { Educative, } \\
\text { informative } \\
\text { measures }\end{array}$ & $\begin{array}{l}\text { Promoting public transportation and } \\
\text { alternative energy sources (e.g. renewables' } \\
\text { promotion since } 1980 \text { 's). }\end{array}$ & $\begin{array}{l}\text { Sensitizing and empowering the public } \\
\text { regarding environmental issues has not } \\
\text { been effective in India. }\end{array}$ \\
\hline
\end{tabular}




\subsubsection{Industries}

Industrial sector (manufacturing, power, mining and quarrying, construction) contributes roughly $20-40 \%$ to urban air pollution in India (Kansal, 2011). In India, due to small and medium enterprises (SME) that consists mainly of small family enterprises, there are significantly more manufacturing industries in urban areas, e.g. in Delhi around 126,000 (DoES, 2000). Very often these industrial units operate illegally with primitive technology and process standards. Thermal power plants (TPPs) are the second biggest contributors to urban air pollution in India. In Delhi, there are four TPPs within the city limits, and another three near the city contributing significantly to the urban air pollution levels (Kansal, 2011). The main fuels used in the industrial sector are fossil fuels (Table 8). Due to the higher number of pollution sources, poor technology, and fuel quality the resulting pollution levels in India is higher (OECD, 2006/07; Chapkhekar and Madhav, 1999).

Table 8. Fuel usage and energy consumption in industrial sector

\begin{tabular}{|l|l|}
\hline Indicator & India \\
\hline Fuel usage in industrial sector: & \\
Coal & $55.0 \%{ }^{1}$ \\
Oil & $29.9 \%{ }^{1}$ \\
Natural gas & $8.5 \%{ }^{1}$ \\
Renewable & $5.6 \%{ }^{1}$ \\
Nuclear energy & $1 \%{ }^{1}$ \\
\hline Energy consumption: & \\
Total & $594.9 \mathrm{Mtoe}^{2}$ \\
Per capita & $529 \mathrm{kgoe}^{2}$ \\
Urban & $167.5 \mathrm{Mtoe}^{2}$ \\
\hline
\end{tabular}

Source: ${ }^{1}$ Bhattacharya, 2009; ${ }^{2}$ World Bank, 2010; Mtoe: Million tonnes of oil equivalent

Some assorted measures that have been taken so far include: closure and/or shifting of polluting industries, strict enforcement of pollution control measures in the remaining industries, compulsory use of beneficiated/blended coal with ash content less than $34 \%$ in all coal based thermal power plants from June 2001 (MoEF, 2001), increase in green cover etc. However, the impacts of such measures are not perceptible (Table 7).

\subsubsection{Air pollution from domestic sectors}

Domestic sector too has its share, although small, in contribution to overall pollution load. According to health impact studies done by World Bank in 2004, indoor air pollution has emerged as one of the prime environmental health concerns in India. The report points out that biomass fuels combine with open chulhas (stoves) and inadequate ventilation create problems with the lives of two major vulnerable groups: children and women. The situation is further aggravated due to the use of inefficient and highly polluting fuels in the poorer households that have low nutritional security and low capacity to pay for health care. For e.g. based on the emission factors for Indian cooking chulhas (stoves), the contribution of domestic sector to air 
pollution includes 3338 tonnes/yr of suspended particulate matter (SPM); 6319 tonnes/yr carbon monoxide (CO); and 859 tonnes/yrNO ${ }_{\mathrm{x}}$ (TERI, 1997).

\section{Policies for sustainable urbanization in India}

The GoI has launched Nation Mission for Sustainable Habitat (NMSH) to addresses urbanization challenges (MoUD, 2010; Planning Commission, 2013a, 2013b, 2013c; NIUA, 2011). Key features are given below:

- Formulation of national migration and population growth policies in order to foster a more balanced geographic pattern of urban growth and economic development. Such policies would also help to designate areas where guided stimulation will be necessary.

- Policies for de-concentration and control of peripheral growth, green belt and ribbon development.

- Policies for growth of centering and major infrastructure provision like transport, communications and power.

- Policies for the reconstruction of the rural landscape, including the development of marketing towns and service centers.

- Metropolitan policies to limit the growth of metropolitan cities, provision of mass transportation facilities and policies for redevelopment of central city areas, urban renewal and slum clearance programs.

- Housing policy to provide mass housing and building rent control measures.

- Policies for checking environmental pollution in cities, particularly water and air pollution.

- Urban land policy including measures like "socializing", urbanizable land, restriction on building plot sizes and simplification of land acquisition procedures.

- Policies for Urban administration, including determination of powers and functions of local bodies and measures to improve their finance, administration and co-ordination of civic services.

As cities are dynamic, complex and connected system, therefore intervention in one aspect of urbanization will influence the other. Benefits incidental to a particular policy goal can help drive the implementation of the policy and sustain it in long term, but only when the inherent risk trade-offs, if present, can be managed. For e.g climate change will worsen the pressure on city infrastructure (INCCA, 2010; MoUD, 2010). Review of mitigation and adaptation strategies of cities reveals that, climate change is in many cases either absent or insufficiently linked to the discourse on overall sustainable urban development (UNHS, 2011). Climate change adaptation strategies in many cases creates the impression it is some separate undertaking, that takes place detached from other on-going discourses, or it is even outside the institutional entities usually dealing with issues related to sustainable urban development (Birkmann et al, 2010).Additionally, it has been found that the disaster risk reduction community and adaptation community, work separately and synergies between them have not been well-established, even 
though both these communities have a common goal of reducing the impacts of extreme events and increasing urban resilience (Solecki et al, 2011). Both these functions are generally housed in different Departments or Ministries with fragmented roles and responsibilities (MoUD, 2010; NIUA, 2011) Also, better land use planning and improved building code, proposed as key adaptation measures, do not often sufficiently match the reality because of existence of informal social mechanisms of land management in India. The probability of finding win-win solutions, for sustainable urbanization, is low, and trade-offs between conflicting goals are more common (Mcevoy et al, 2006). For example, energy efficiency related mitigation measures are considered as the low hanging fruits of a city's responses to climate change (Dodman, 2009). However, implementing these measures in existing infrastructure might generate waste consisting of fully working devices. Hence, climate change mitigation and adaptation measures are at times associated with conflicts and trade-offs of competing goals of sustainable development strategies and hence is a decisional challenge for planners and the city administration. Further, mitigation strategies for individual cities may deprive other areas for mitigating their emissions if the reductions are achieved by outsourcing emission-intensive sectors. To avoid problem shifts between regions, it is essential to complement the analysis of individual cities with analyses at larger scales.Assessment of how cities and countries have progressed with respect to execution of existing sustainability agendas and mitigation and adaptation plans in a depressed economic scenario would help identify the determinants of successful urban sustainable development strategies.

\section{Reference}

1. Batool, S.A., \& Muhammad, Nawaz. Ch., 2009. Waste Management. Municipal solid waste management in Lahore City District, Pakistan. 29, 1971-1981.

2. Bose, R., Sperling, D., 2001. Transportation in developing countries: Greenhouse gas scenario for Delhi, India, Paper prepared for the Pew Center on Global Climate Change. Arlington, VA, pp 43. (Publication No. UCD-ITS-RP-01-13).

3. Bhattacharya, S.C., Chinmoy, J., 2009. Renewable energy in India: Historical developments and prospects. Energy. 34, 981-991.

4. Birkmann, J., Garschagen, M., Kraas, F., Quang, N., 2010. Adaptive urban governance: new challenges for the second generation of urban adaptation strategies to climate change. Sustainability Science. 5, 185-206.

5. Chaphekar, S.B., Madav, R.P., 1999. Thermal power plants and environmental management. Journal of Indian Association for Environmental Management. 26(1), 48-53.

6. CityMayors.com. the Largest Cities in the World by Land Area, Population and Density http://www.citymayors.com/statistics/urban-population-numbers.html

7. CPCB. 1996. Annual report 1995/96, Central Pollution Control Board (CPCB), Ministry of Environment\& Forests, Government of India, New Delhi, pp. 1-165. 
8. CPCB, 2000. National ambient air quality status and statistics 1998 [National Ambient Air Quality and Monitoring Series: NAAQMS/15/2000-01]. Central Pollution Control Board (CPCB) Ministry of Environment \& Forests, Government of India, New Delhi, pp 120.

9. CPCB, 2002. National ambient air quality status and statistics 2000 [National Ambient Air Quality and Monitoring Series: NAAQMS/22/2001-02]. Central Pollution Control Board (CPCB) Ministry of Environment\& Forests, Government of India, New Delhi, pp 161.

10. CPCB, 2004. National ambient air quality status and statistics 2002 [National Ambient Air Quality and Monitoring Series: NAAQMS/24/2003-04]. Central Pollution Control Board (CPCB) Ministry of Environment \& Forests, Government of India,New Delhi, pp 167.

11. CPCB, 2005. Status of Sewage Treatment in India. Central Pollution Control Board (CPCB)Ministry of Environment\& Forests, Government of India,New Delhi, pp 1-101.

12. CPCB, 2011. National Ambient Air Quality Status 2009, [NAAQMS//2010-11] Central Pollution Control Board (CPCB) Ministry of Environment \& Forests, Government of India. New Delhi.

13. CRRI, 2003. Losses of petroleum products at traffic intersections due to idling of vehicles at Delhi. Central Road Research Institute (CRRI). New Delhi.

14. Census of India, 2001. Registrar General and Census Commissioner, Ministry of Home Affairs, Government of India.New Delhi http://censusindia.gov.in/

15. Census of India, 2011. Registrar General and Census Commissioner, Ministry of Home Affairs, Government of India. New Delhi.

http://censusindia.gov.in/

16. DUEIIP. 2001. Base study for white paper for industries in Delhi, Delhi Urban Environment and Infrastructure Improvement Project (DUEIIP), Government of Delhi, New Delhi.

17. DoES, 2000. Delhi Statistical Handbook. Directorate of Economics and Statistics (DoES) Government of National Capital Territory of Delhi, New Delhi.

18. Dodman, D., 2009. Blaming cities for climate change? An analysis of urban greenhouse gas emissions inventories. Environment and Urbanization. 21, 185 -201.

19. Dwivedi, R.M., 2007. Urban development and Housing in India 1947-2007, New Century Publication, pp 9-10.

20. Economic Survey of Delhi, 2012-13. Government of Delhi. Chapter 13,pp 178-191. http://delhi.gov.in/DoIT/DoIT_Planning/ES2012-13/EN/ES_Chapter13.pdf

21. Eurostat Statistics 2010. Transport. http://epp.eurostat.ec.europa.eu/portal/page/portal/transport/data/main_tables

22. Financial express, 2003. CII initiative for public private partnership to tide over water crisis. New Delhi: Indian express group.

23. Ghose, M. K., Paul, R., Banerjee, S. K., 2004. Assessment of the impacts of vehicular emissions on urban air quality and its management in Indian context: the case of Kolkata (Calcutta). Environmental Science \& Policy. 7, 345-351.

24. GNCTD. 1999. Delhi statistical Handbook.Directorate of Economics \& Statistics. Government of National Capital Territory. Delhi (GNCTD): New Delhi, pp, 1-325. 
25. Hindustan Times 2012, Water Solution in Slum clusters, November 15, pp 3.

http://paper.hindustantimes.com/epaper/viewer.aspx

26. INCCA, 2010. India: Greenhouse Gas Emissions 2007. Indian Network for Climate Change Assessment, Greenhouse Gas Emissions (INCCA). Ministry of Environment and Forests, Government of India.

27. IPE, 2004. Management of Solid waste in Indian cities. Infrastructure Professionals and Enterprise Ltd, New Delhi, Oxford University Press.,New Delhi, pp 257.

28. Kansal, A., 2002. Solid waste management strategies for India. Indian Journal of Environmental Protection. 22 (4), 444-448.

29. Kansal, A., 2001. Critical appraisal of solid waste disposal technologies. Indian Journal of Environment Protection. 19(3), 83-96.

30. Kansal A., Khare M., and Sharma C. S., (2011). Air quality modeling study to analyze the impact of the World Bank emission guidelines for thermal power plants in Delhi. Journal of Atmospheric Pollution Research (2): 99-105.

31. Kumar, S., Bhattacharyya, J.K., Vaidya, A.N., Chakrabarti, T., Devotta, S., Akolkar, A B., 2009. Assessment of the Status of Municipal Solid Waste Management in Metro Cities, State Capitals, Class I Cities and Class II Towns in India: An Insight Central Pollution Control Board (CPCB), National Environmental Engineering Research Institute (NEERI). Waste Management. 29, 883895.

32. Mahadevia, D., 2010. Urban Reforms in Three Cities: Bangalore, Ahmadabad and Patna. In Chand.V (eds.), Public Service Delivery in India: Understanding the Reform Process., Oxford University Press.

33. Mahajan., R. 2001. Integrating health costs and benefits and fuel savings in framing fiscal instruments to control vehicular pollution-a case study of Delhi, M.Sc. thesis: GGS Indraprstha University, Delhi, pp 1-95.

34. Mcevoy, Lindley. S., Handley, J., 2006. Adaptation and mitigation in urban areas: synergies and conflicts. Proceedings of the ICE Municipal Engineer. 159, 185-191.

35. MoEF, 2000, Municipal Solid Waste (Management and Handling) Rules, 2000.The Gazette of India.Ministry of Environment and Forests (MoEF), Government of India. New Delhi.

36. MoEF, 2001. Annual report 2000/2001, Ministry of Environment and Forests (MoEF), Government of India, New Delhi, pp. 1-212.

37. MoEF, 2009. State of Environment Report, Ministry of Environment and Forests (MoEF), Government of India, New Delhi

38. MoUD, 2008. National Urban Sanitation Policy. Ministry of Urban Development, Government of India. Ministry of Urban Development (MoUD), Government of India, New Delhi.

39. MoUD, 2010. National Mission on Sustainable Habitat. Ministry of Urban Development (MoUD), Government of India, New Delhi.

40. MoUD, 2012. Improving Water supply and sanitation services, Ministry of Urban Development (MoUD), Government of India, New Delhi,pp 1-28. 
41. MHFW, 2008. Ministry of Health and Family Welfare. National Health Profile 2007. Central Bureau of Health Intelligence, Directorate General of Health Services, Government of India, New Delhi.

42. MoRTH, 2005. Motor transport statistics of India, 2002/03. New Delhi: Transport Research Wing, Ministry Of Road Transport and Highways (MoRTH). Government of India. New Delhi.

43. MoRTH, 2009. Basic Road Statistics of India, Ministry of Road Transportation and Highways (MoRTH). Government of India, New Delhi.

44. MoRTH, 2012. Outcome Budget 2011-12, Ministry Of Road Transport and Highways (MoRTH).Government of India. New Delhi.

45. Mail Today, 2011. Delhi traffic will crawl at 5kmph. Mail Today, New Delhi, India.

46. MMRDA, 1999. Regional Plan for Mumbai Metropolitan Region 1996-2011, Mumbai Metropolitan Regional Development Authority (MMRDA). Mumbai.

47. MoST, 1996.Motor transport statistics of India-1995. Transport Research Wing. Ministry of Surface Transport (MoST), Government of India, New Delhi, pp1-125.

48. NIUA, 2005. Status of Water Supply, Sanitation and Solid Waste Management. National Institute of Urban Affairs. Government of India. New Delhi.

49. NIUA, 2011. Report on Indian urban infrastructure and services. National Institute of Urban Affairs (NIUA). Ministry of Urban Development. Government of India. New Delhi

50. Nema, A.K., 2004. Collection and transport of municipal solid waste. In: Training Program on Solid Waste Management. Springer, Delhi, India.

51. NCERT, 2002. Seventh All India School Education Survey 2002. National Council of Educational Research and Training (NCERT). Government of India. Delhi.

52. TapanNarayana, 2009. Municipal solid waste management in India: From waste disposal to recovery of resources? Waste Management. 29, 1163-1166.

53. OECD (2009), "Municipal waste”, in OECD Factbook 2009: Economic, Environmental and Social Statistics, OECD Publishing. http://dx.doi.org/10.1787/factbook-2009-67-en

54. OECD Environmental Data, 2006/7. Compendium 2006/7 on air.

55. Pangotra, P., Sharma, S., 2010.Modelling travel demand in a Metropolitan city: case study of Bangalore, India. http://www.iimahd.ernet.in/publications/data/2006-03-06ppangotra.pdf

56. Plappally, A.K.,Lienhard V. J.H., 2012. Energy requirements for water production, treatment, end use, reclamation, and disposal. Renewable and Sustainable Energy Reviews.16, 4818-4848.

57. Planning commission 2002, Water Supply and Sanitation, A WHO-UNICEF sponsored study, India assessment, Planning Commission, Government of India, New Delhi. 1-71.

58. Planning commission, 2008. Report on eleventh five year plan (2007-2012). Planning commission Government of India. III, 1-280.

59. Planning Commission, 2011a. Report of the working group on disease burden for the 12th five year plan. Planning Commission, Government of India. New Delhi. 
60. Planning Commission, 2011b. Report of the Working Group on Urban and Industrial Water Supply and Sanitation for the Twelfth Five-Year- Plan (2012-2017). Planning Commission. Government of India. New Delhi.

61. Planning commission, 2013. Faster, sustainable and more inclusive growth, an approach to $12^{\text {th }}$ Five year (2012-2017). Draft report. Planning Commission. Government of India. I, 1-360.

62. Planning commission, 2013b. Economic sectors, $12^{\text {th }}$ Five year (2012-2017). Draft report, Planning Commission. Government of India. II, 1-438.

63. Planning commission, 2013c. Social sectors, $12^{\text {th }}$ Five year (2012-2017). Draft report, Planning Commission. Government of India. III, 1-292.

64. Pundir, B.P., 2001. Vehicular Air Pollution in India: Recent Control Measures and Related Issues, in India Infrastructure Report 2001, edited by S Morris. Oxford University Press, New Delhi.

65. Pune Municipal Corporation, 2011. Revised city development plan for Pune - 2041, Maharashtra, under JNNURM

http://www.punecorporation.org/pmcwebn/informpdf/CDP/2_CDP_Physical_Social_infra.pdf

66. Singh, S.K., 2005. Review of urban transportation in India,Journal of Public Transportation, 8(1).

67. Sengupta., B. 2000. Steps taken to control vehicular pollution in India. Paper presented in International Workshop by SIAM 4-5 Dec 2000, Ministry of Environment and Forests (MoEF), Government of India, New Delhi.

68. Sharholy, M., Ahmad, K., Mahmood, G., Trivedi, R.C., 2008. Municipal solid waste management in Indian cities - A review. Waste Management 28, 459-467.

69. Shekdar, A. V., 2009. Sustainable solid waste management: An integrated approach from Asian Countries Waste Management 29, 1438-1448.

70. SIAM, 2008. The Indian automobile industry: statistical profile 2007-08. Society for Indian Automobile Manufacturers (SIAM). New Delhi

71. Slum Census of India, 2001. Registrar General and Census Commissioner, Slum Population in Million Plus Cities (Municipal Corporations): Part A, Ministry of Home Affairs, Government of India

http://censusindia.gov.in/Tables_Published/Admin_Units/Admin_links/slum1_m_plus.html

72. Singh, S. P., 2005. Sulabh Sanitation Movements: Vision 2000 plus, $4^{\text {th }}$ edition. New Delhi: Sulabh International Social Service Organization

73. Solecki, W., Leichenko, R. and O'Brien, K., 2011. Climate change adaptation strategies and disaster risk reduction in cities: connections, contentions, and synergies. Current opinion in Environmental Sustainibility. 3(3), 135-141.

74. Transport India, 2010. Indian Road Network in Road statistics. http://www.transportindia.in/indian_roads.asp

75. The Hindu 2011, Ammonia Level in Delhi water rises again, $2^{\text {nd }}$ March, 2011 http://www.thehindu.com/todays-paper/tp-national/tp-newdelhi/ammonia-level-in-delhi-waterrises-again/article1502522.ece

76. TERI, 1997.Natural resource accounting in the Yamuna sub-basin (Report no. 95/EM/61), Tata Energy Research Institute,TERI, New Delhi, pp 1-230. 
77. TERI, 1998. Looking back to think ahead: Green India 2047. The Energy and Resource Institute,TERI, New Delhi, pp346.

78. TERI, 2002. Impact of population on water and the quality of life. [Project report no. 1999d42]. Submitted to United Nations Population Fund, The Energy and Resource Institute, TERI,New Delhi.

79. TERI, 2006. Study on compensation to resource-bearing states. [Project report no. 2006d21], The Energy and Resource Institute, TERI. Submitted to international council secretariat, Ministry of Home Affair, Government f India, New Delhi.

80. TERI, 2009. An exploration of sustainability in the provision of basic urban services in Indian cities, TERI in partnership with Sustainable Urbanism International and Arghyam, The Energy And Resource Institute, TERI, New Delhi.

81. TERI, 2010. Looking Back to Think Ahead: Green India 2047 renewed. The Energy and Resource Institute, TERI,New Delhi.

82. Troschinetz, A.M., Mihelcic, J.R., 2009. Sustainable recycling of municipal solid waste in developing countries. Waste Management. 29, 915-923.

83. UNHSP, 2010. United Nation Human Settlement Program. The Challenge of Slums: Global Report on Human Settlements 2010. Earthscan 4 Publications, London; Sterling, VA.

84. United Nations, Department of Economic and Social Affairs, Population Division, 2012. World Urbanization Prospects: The 2011 Revision, CD-ROM Edition, File 1: Population of Urban and Rural Areas and Percentage Urban, 2011POP/DB/WUP/Rev.2011/1/F1 http://esa.un.org/unup/

85. UBA, 2009. Daten zum Verkehr, Berlin: Umweltbundesamt.

86. Uiterkampa, B.J.S., Azadib, H., Ho, P., 2008. Sustainable recycling model: A comparative analysis between India and Tanzania. Resources, Conservation and Recycling. 55, 344-355.

87. Vesilund, P. A., 1982. Environmental Engineering, Butterworth Publishers, Boston, 1982.

88. World Bank, 2002. Indian transport sector: The challenges ahead, Background Papers. Energy and Infrastructure Sector Unit, South Asia Region. Vol. 2.

89. World Bank, 2004. Air Pollution Associated With Household Fuel Use In India. Washington, DC: World Bank

90. World Bank, 2006. Improving Management of Municipal Solid Waste in India: Overview and Challenges. World Bank.

91. World Bank, 2010. World data bank: World Development Indicators (WDI) \& Global Development Finance (GDF).

92. http://databank.worldbank.org/ddp/home.do

93. WSA, 2008. Traffic and transportation policies and strategies in urban areas in India. Wilbur Smith Associates (WSA). http://urbnaindia.nic.in/mod/programme/ut/traffic_transportation.pdf>

94. World Resources Institute, 2011. Earth Trends - The Environmental Information Portal, Transportation statistics http://earthtrends.wri.org 